\title{
A INTENCIONALIDADE NA REALIZAÇÃO DE TRABALHOS EM GRUPO NA SALA DE AULA: O OLHAR DE UMA PROFESSORA
}

\section{Bruna Celli D’Abruzzo Degrecci*, Ana Maria Falcão de Aragão}

\section{Resumo}

As contribuições desse estudo são no sentido de que, ao ser conhecida a intencionalidade docente para a realização de trabalhos em grupo na sala de aula, seja possível colaborar com a compreensão de um trabalho docente cada vez mais intencional e menos ingênuo.

\section{Palavras-chave:}

Trabalho em grupo, zona de desenvolvimento iminente, observação em classe

\section{Introdução}

Por trabalho em grupo compreendemos a reunião entre indivíduos que possuem uma necessidade comum. Este aspecto os motiva a estarem juntos. Contudo, nesta relação há também a ideia de aprendizado mútuo, de construção de conhecimento através de um processo de interação entre os indivíduos. Por intencionalidade docente entendemos todas as ações tomadas pelo professor para a formação de seu aluno, uma vez que quem educa tem um objetivo a ser alcançado, uma intenção, ao ser conhecida. Assim, ao conhecermos a intencionalidade docente para a realização de trabalhos em grupo na sala de aula, é possível colaborar com a compreensão de um trabalho docente cada vez mais intencional e menos ingênuo. O objetivo é conhecer as estratégias utilizadas por uma professora para a realização de atividades em grupo por seus alunos, bem como sua intencionalidade, as suas justificativas e os seus fundamentos para a implementação desse trabalho

\section{Resultados e Discussão}

Beatriz me mostrou que uma aula deve atingir as necessidades de cada grupo de alunos, visando fazer com que, em agrupamentos, cada aluno construa seus conhecimentos. O Outro, então, tem papel essencial na construção do ser humano, uma vez que deste é um ser social.

A intencionalidade na realização de trabalhos em grupos é uma questão fundamental para que a atividade dê certo. $\mathrm{O}$ que eu quero com essa atividade? Pensar o que se espera que os alunos aprendam com ela, como espera que eles trabalhem, qual é a necessidade do aluno que quer pontuar com a atividade.
Todas essas questões devem estar bem claras para o professor no momento do planejamento, o qual é outro ponto importante destacado pela professora. Planejar as atividades com base em sua intenção e também pensando em trazer nela desafios para instigar o aluno a ir além do que já conhece.

A prática de agrupamentos condiz com qualquer teoria. Ou seja, ela é adaptável ao jeito de cada professor então, isso faz dos agrupamentos uma técnica flexível. É possível encontrar outros caminhos da realização de trabalhos em grupo.

Conhecer os alunos, entender como eles se relacionam, somente é possível quando temos uma relação com cada um deles. Depois de compreender como se dão as relações interpessoais da sala de aula, a montagem dos grupos, trios e duplas fica a critério da intencionalidade do professor com a atividade. Dessa maneira, a não realização do trabalho proposto fica com menor probabilidade de acontecer.

\section{Conclusão}

É indiscutível o papel fundamental do trabalho em grupo ou qualquer outra denominação que ele receba para o processo de ensino e aprendizagem dos alunos. Saber trabalhar com ele é tarefa que demanda ao professor planejamento, conhecimento sobre cada um de seus alunos (tanto em relação aos seus conhecimentos quanto as suas características pessoais) e reflexão sobre sua prática.

\section{Agradecimentos}

Agradeço ao GEPEC (Grupo de Estudos e Pesquisa em Educação Continuada) e ao PIBIC/CNPq, pelo apoio dado à pesquisa. 